\title{
The doctors' dilemmas: Medical practice in the Free State during the South African War
}

\author{
John Boje*
}

\begin{abstract}
At the end of the nineteenth century, the actions of belligerents were constrained by the Hague Convention of 1899 and the Geneva Convention of 1864. The Hague Convention differentiated between combatants and non-combatants, but both the British implementation of a scorched earth policy and the Boer execution of blacks violated this convention. The Geneva Convention centred on medical immunity, which presupposes medical neutrality. The British opposed the voluntarism fundamental to the Red Cross movement and all British medical personnel in the field were subservient to the military establishment. Imperial patriotism, the shortcomings of the army and the insistent claims of military necessity subverted best medical practice, producing dilemmas that doctors had to negotiate. On the Boer side too, there was the moral complexity of doctors who were not only medical professionals but also social agents with personal commitments. This article considers the dilemmas that confronted doctors involved in the South African War in the Free State and concludes that trends in dealing with ethical challenges in this war became normative in subsequent conflicts.
\end{abstract}

Key words: South African War; Free State; military medicine; Hague Convention; Geneva Convention; civilians; neutrality.

\section{Opsomming}

Teen die einde van die neëntiende eeu is die gedrag van oorlogvoerendes in bedwang gehou deur die Haagse Konvensie van 1899 en die Geneefse Konvensie van 1864. Die Haagse Konvensie het tussen vegtendes en nie-vegtendes onderskei, maar beide die Britse toepassing van 'n verskroeide aardebeleid en die Boere se teregstelling van swartes was skendings van dié konvensie. Die Geneefse Konvensie het gesentreer op mediese immuniteit, wat neutraliteit veronderstel. Die Britse owerhede was gekant teen die volutarisme wat grondliggend aan die Rooikruisbeweging was en al hul mediese personeel te velde was ondergeskik aan die militêre gesag. Imperiale patriotisme, die tekortkominge van die leër en die volgehoue aandrang op militêre

* John Boje is a research associate of the Department of Historical and Heritage Studies, University of Pretoria. He is the author of An Imperfect Occupation: Enduring the South African War (University of Illinois Press, Urbana, 2015).

How to cite this article: J. Boje, "The doctors' dilemmas: Medical practice in the Free State during the South African War", Historia, 63, 1, May 2018, pp 45-71. 
noodsaaklikheid het optimale mediese sorg belemmer. Ook aan Boerekant was daar die morele kompleksiteit dat dokters nie net professionele praktisyns was nie maar ook sosiale betrokkenes met persoonlike verbintenisse. In hierdie artikel word die dilemmas in oënskou geneem waardeur dokters betrokke in die Suid-Afrikaanse Oorlog in die Vrystaat gekonfronteer is en word daar tot die gevolgtrekking gekom dat tendense waarneembaar in hierdie oorlog waardeur morele uitdagings die hoof gebied is in latere konflikte normatief geword het.

Sleutelwoorde: Suid-Afrikaanse Oorlog; Vrystaat; militêre geneeskunde; Haagse Konvensie; Geneefse Konvensie; burgerlikes; neutraliteit.

\section{Introduction}

According to the World Medical Association (WMA) there is no difference between medical ethics in peacetime and in war. ${ }^{1}$ If that were indeed the case, medical personnel in the Free State would have experienced far fewer dilemmas and there would have been no basis for the present article. However, the WMA's claim is contradicted by the moral complexity arising from the fact that medical personnel are also social actors whose professional responsibilities do not always sit comfortably with their personal commitments, ${ }^{2}$ whether to an ideology, a country or an institution. At the close of the nineteenth century, the normative context of medical practice in time of war - what is now called international humanitarian law reflected this conflict, deriving from both the Hague Convention of 1899 and the Geneva Convention of $1864 .{ }^{3}$ But war overwhelms bioethical concerns, curtailing the right to life and impinging on the concomitant right to medical care, ${ }^{4}$ so the purpose of this article will be to show how British, colonial, European and Boer doctors in the Free State sought to negotiate conflicting loyalties and to constrain military excess by their adherence to humanitarian principles.

\section{The Hague Convention}

At the heart of the Hague Convention was the principle of discrimination applied to combatants and civilians. ${ }^{5}$ The assumptions underlying the protection accorded civilians were that there was no advantage to be gained from acting against them and

1. M.L. Gross, "Bioethics and Armed Conflict: Mapping the Moral Dimensions of Medicine and War", Hastings Center Report, 34, 6 (2004), p 22.

2. C. Rochon, "Dilemmas in Military Medical Ethics: A Call for Conceptual Clarity", BioéthiqueOnline 4/26 (2015), http://bioethiqueonline.ca/4/26, accessed 15 April 2017.

3. F. Kalshoven and L. Zegveld, Constraints on the Waging of War: An Introduction to International Humanitarian Law (International Committee of the Red Cross, Geneva, 2001), p 15.

4. Gross, "Bioethics and Armed Conflict", p 23.

5. S.P. Lee, Ethics and War: An Introduction (Cambridge University Press, Cambridge, 2012), pp 156-157. 
that they, for their part, would refrain from any kind of military involvement. ${ }^{6}$ During the South African War these assumptions became increasingly problematic and in subsequent wars they gave rise to even more intractable dilemmas.

The British commander-in-chief, Lord Wolseley, opposed adherence to the convention as "prejudicial to our military interests",7 contending that commanders in the field should not have their hands tied in any way. Lord Roberts, his commander in the South African War field, lost no time in implementing martial law, "as such law is understood and administered in British territory and by British officers". 8 This was subsequently defined more precisely as "the will of the conqueror ... limited in its operation only by what is known as the customs of war and the discretion of those who administer it". ${ }^{9}$ These elucidations exemplify the enigma of martial law: it is the means by which an occupying power committed to legality at home, abrogates the rule of law in order to give a semblance of legality to its military operations abroad. ${ }^{10}$ Thus the concession of "military necessity" in Article 23 of the convention was elevated into an overarching principle that exonerated departures from its provisions. ${ }^{11}$ There were many such departures, examined in S.B. Spies's magisterial study, ${ }^{12}$ but the scorched earth policy implemented by the British army may be regarded as a comprehensive and calculated attack on an entire civilian population.

The Boers, whose humanitarianism was constrained by ethnicity, also violated the convention in this regard. The British records list 235 incidents of unarmed blacks being killed by Boers in the field, ${ }^{13}$ including the shooting near Virginia, as early in the war as November or December 1900, of two men accused of showing British troops the road to Ventersburg. ${ }^{14}$ The Boers regarded the black inhabitants of

6. C. Bruderlein and J. Leaning, "New Challenges for Humanitarian Protection", British Medical Journal, 319, 7207 (14 August 1999), p 430; Lee, Ethics and War, p 173.

7. National Archives of the United Kingdom (hereafter NAUK), War Office Records (hereafter WO) 32/850, 589, quoted in S.B. Spies, Methods of Barbarism? Roberts and Kitchener and Civilians in the Boer Republics, January 1900-May 1902 (Human \& Rousseau, Cape Town, 1977), p 14.

8. Parliamentary Papers published by Command of the Government (hereafter Cd), 426, Army Proclamations issued by Field Marshal Lord Roberts in South Africa (1900), XII, p 6.

9. National Archives of South Africa (hereafter NASA), Archives of the Military Governor, Pretoria (hereafter MGP), 260, Army Order 19 November 1900.

10. See D. Dyzenhaus, "The Puzzle of Martial Law," University of Toronto Law Journal, 59, 1 (2009), p 12.

11. K. Surridge, "An Example to be Followed or a Warning to be Avoided? The British, Boers, and Guerrilla Warfare, 1900-1902", Small Wars and Insurgencies, 23, 4-5 (December 2012), pp 609, 614.

12. Spies, Methods of Barbarism?

13. T. Pakenham, "Africans in the Boer War", Review of Peter Warwick, Black People and the South African War, 1899-1902, in Journal of African History, 27, 3 (1986), pp 574575.

14. Cd 821, Correspondence relative to the Treatment of Natives by the Boers, 1901, p 5. See also NASA, Photocopy (hereafter FK) 1849. 
the Free State as their subjects and any black involvement in the war on the side of Britain as an act of insurrection. Furthermore, as J.F.C. Fuller put it, the arming of blacks broke down "the tradition and the rule which had enabled the white man to conquer and occupy South Africa". ${ }^{15}$ As a result of the British policy of clearing the land, any black man encountered was assumed to be a spy and if he was armed, the evidence was regarded as conclusive and he was shot - even without benefit of a trial. ${ }^{16}$ Consequently, towards the end of the war there was little chance of a black prisoner being spared. ${ }^{17}$

\section{The Geneva Convention}

The signal achievement of the Geneva Convention of 1864 was the neutralisation of medical personnel, equipment, hospitals, ambulances and transports in order to safeguard care for the sick and wounded. ${ }^{18}$ At the congress that negotiated the terms of the convention, the British representative opposed the principle of voluntarism, and the Duke of Cambridge, the then commander-in-chief, dismissed the concept as "impracticable". Florence Nightingale was also insistent that voluntary societies would merely dilute the government's responsibility for the sick and wounded. ${ }^{19}$ In consequence, no local Red Cross Committee was established and Britain did not attend international Red Cross conferences, ${ }^{20}$ looking askance at the "irresponsible Committee of Swiss gentlemen" who "perform no function that is of real importance". ${ }^{21}$ The British National Society for Aid to the Sick and Wounded (NAS), established in 1870 was amalgamated with other volunteer movements to form the Central British Red Cross Committee (CBRCC) only in 1899, and this new Red Cross was unequivocally subservient to the medico-military establishment. ${ }^{22}$

15. J.F.C. Fuller, The Last of the Gentlemen's Wars: A Subaltern's Journal of the War in South Africa 1899-1902 (Faber \& Faber, London, 1937), p 152.

16. War Museum of the Boer Republics (hereafter WMBR), 5107/1: "Herinneringe van H.L. Claasen".

17. P. Warwick, Black People and the South African War, 1899-1902 (Ravan, Johannesburg, 1983), p 23; R.D. McDonald, 'n Terugblik op my Oorlogsjare (War Museum of the Boer Republics, Bloemfontein, 1995), p 49.

18. Kalshoven and Zegveld, Constraints on the Waging of War, pp 27, 56.

19. R. Gill, "The Origins of the British Red Cross Society and the Politics and Practices of Relief in War, 1870-1906", Asclepio, 66, 1 (2014), p 4.

20. C.J. de Villiers, "The Geneva Convention, National Red Cross Societies and the AngloBoer War", in A Century is a Short Time: New Perspectives on the Anglo-Boer War (Nexus Editorial Collective, Pretoria 2005), pp 162-164; and Gill, "The Origins of the British Red Cross Society", p 4.

21. A letter writer to the Times, quoted by Gill, "The Origins of the British Red Cross Society", p 2.

22. Gill, "The Origins of the British Red Cross Society", pp 2, 8. 


\section{Imperial nationalism}

Neither British nor colonial medical personnel would have escaped the ambiguity of reconciling their professional mission to alleviate the distress of all, including the enemy, with the sustained campaign of pro-imperial activity which vilified the enemy in order to justify the war. ${ }^{23}$ A newly qualified doctor, John McCrae, who was moved by patriotic fervour to serve as a lieutenant in the Royal Canadian Artillery was troubled by the "inner conflict between the life-saving doctor and the death-dealing artillerist."24

For a doctor overly imbued with such fervour, the convention of medical immunity could serve as a useful cover for espionage. This is why the Boers besieged at Paardeberg declined the British offer of medical assistance unless the doctors were blindfolded when they entered the Boer lines. ${ }^{25}$ A wounded British doctor, Dr J.G. Willis in the care of the 1st Netherlands Ambulance, was suspected by the Boers of being a spy. The Boer nurse Betty Wessels mentions this in her journal, and the tension between her patriotism and the trust the doctor's immunity should bestow is palpable in the entry: "He says they treat him like a criminal. He is guarded and has no one to talk to. What could I do? I should very much like to help him, but how? I won't do any harm to my country." 26

\section{The Royal Army Medical Corps}

The intransigence of the British army and the unpreparedness of its medical services are factors of great historical significance because major humanitarian crises arose from the inability to deal with outbreaks of disease in concentrations both of military personnel, most notably the typhoid epidemic that caused the death of more soldiers than enemy action, and of civilian populations in the white and black concentration camps.

The doctors of the Royal Army Medical Corps (RAMC) all held military rank and almost half of the civil surgeons who supplemented the seriously understaffed

23. Compare S. Marks, "British Nursing and the South African War", in G. Cuthbertson, A.M. Grundlingh and M-L. Suttie, Writing a Wider War: Rethinking Gender, Race, and Identity in the South African War, 1899-1902 (Ohio University Press, Athens, OH, 2002), p 175.

24. J.E. Hurst, "John McCrae's Wars", in B.C. Busch (ed.), Canada and the Great War: Western Front Association Papers (McGill University Press, Montreal, 2003), p 69.

25. C. de Jong, Buitelandse Ambulances in de Tweede Anglo-Boerenoorlog (C. de Jong, Amsterdam, 1999), p 26.

26. B. Wessels, "Diary of Betty Wessels: Winburg 8th May 1900 to Lourenco Marques 19th October 1900" (Photocopy, African Stockdale Collection, University of the Free State), 29 July 1900, p 42. Dr Willis was wounded on 16 July 1900 and left for England on the hospital ship Simla on 27 August. See https://www.angloboerwar.com/otherinformation/86-shipping-records/1805-shipping-records-september-1900, accessed 13 May 2017. 
and underprepared RAMC were engaged by the War Office. ${ }^{27}$ The Army Nursing Reserve and members of the British Red Cross and St John's Ambulance Brigade were completely subordinate to the RAMC ${ }^{28}$ and even in the midst of the typhoid epidemic in Bloemfontein, the Red Cross was hampered in its work. ${ }^{29}$ Furthermore, the RAMC had a lowly status in the army hierarchy. Lord Roberts disparaged Surgeon Maj. Gen. W.D. Wilson, the head of the corps, as "a poor creature [who] does not seem to have any idea what is required". ${ }^{30}$ Army doctors were looked down on by their fellow officers and were not consulted on vital health matters such as the siting of camps. ${ }^{31}$ Medical orderlies were poorly trained and the introduction of nursing sisters was resisted strenuously. ${ }^{32}$

Because RAMC doctors were part of the British army, they had to obey orders even if these impacted negatively on their medical responsibilities. In a highly critical report on medical arrangements in South Africa, William Burdett-Coutts cites the example of an army surgeon who was placed in the invidious position of having to move twenty dangerously ill patients even though it was clearly wrong to do so. "The order had come to evacuate the hospital; the medical officer had no choice but to obey." In the space of three days, four of the twenty had died. ${ }^{33}$

Because of the structural inadequacies of the RAMC, doctors had to confront situations that were so overwhelming that they were frustrated in their humanitarian commitment. The RAMC was very successful in its treatment of 22000 soldiers for wounds and injuries, but failed in the treatment of twenty times that number for preventable diseases, including 74000 who suffered from typhoid and dysentery. ${ }^{34}$ They were, furthermore, inhibited in their ability to report on culpable mismanagement. Yet others did so. John McCrae said of the De Aar military hospital:

No RAMC for me or any other MC. There is a big breach and the medicals are on the far side of it. For absolute neglect and rotten administration, it is a model. I

27. J.C. de Villiers, Healers, Helpers and Hospitals, 2 volumes (Protea, Pretoria, 2008), volume I, pp 148-150, 166.

28. De Villiers, Healers, Helpers and Hospitals, volume I, pp 170-174.

29. E. van Heyningen, "The South African War as Humanitarian Crisis", International Review of the Red Cross, 97 (2015), p 1023.

30. M. Carver, The National Army Museum Book of the Boer War (Sidgwick \& Jackson, London, 1999), p 133.

31. E.M. Spiers, The Late Victorian Army 1868-1902 (Manchester University Press, Manchester, 1992), p 375.

32. Carver, The National Army Museum Book, 133.

33. W. Burdett-Coutts, The Sick and Wounded in South Africa: What I Saw and Said of Them and of the Army Medical System (Cassell, London, 1900), p 29. For another striking example see I. Robertson (ed.), Cavalry Doctor: Letters Written from the Field 19001901 during the Anglo-Boer War by Col. A.F. Russell MB CMG (I. Robertson, Constantia, 1979), 31 October 1901, p 301.

34. E. Benton, "British Surgery in the South African War: The Work of Major Frederick Porter", Medical History, 21, 3 (1977), p 289. 
am ashamed of some members of my profession. Every day 15 to 30 Tommies die from fever or dysentery. 35

In the British camps at Paardeberg, the sick and wounded lay on the ground, exposed to the elements, but an army doctor, Wilson Cheyne, later made light of it, saying that their hardships were of little consequence. ${ }^{36}$

When Roberts entered Bloemfontein on 13 March 1900 he had 200 sick and wounded; by 1 June there were close on 4000 patients and, without the personnel and resources to cope, men died in appalling dirt and distress. A British soldier wrote: : "All the stuff that has been written about the military hospitals and the care given of the sick and wounded is lies ... as for Tommy Atkins, no one cares a straw whether he lives or dies", 37 and this was confirmed by a civilian doctor, Albert Morison: "Believe everything you hear as to mismanagement and even incapacity and wilful neglect ... You would be surprised how the 'Tommies' cringe from me because of the R.A.M.C. badges on my shoulder...".38

When a Royal Commission was sent to South Africa to investigate, concern for their future careers made most RAMC doctors reluctant to report negatively, ${ }^{39}$ while civilian doctors were prevented by their contracts from divulging hospital matters. ${ }^{40}$ The Romer Commission found that "taken all in all, in no campaign have the sick and wounded been so well looked after as in this". ${ }^{11}$ When a second enquiry, the Elgin Commission, was appointed after the war, Frederick Treves, one of the civilian doctors involved, was less conflicted and could be rather more forthright in the evidence he gave. ${ }^{42}$

\section{Immunity of ambulances}

Because the British commanders were generally ignorant of the provisions of the Geneva Convention, there were a number of serious infringements of the immunity of ambulances. ${ }^{43}$ In the early stages of the war, there was a tendency to acknowledge

35. Hurst, "John McCrae's Wars", pp 69-70.

36. B. Farwell, The Great Boer War (Penguin Books, London, 1976) p 212, with reference to Cd 453, p 23.

37. Pvt. T.G.P. Humphreys, "Black and White Budget", 18 August 1900, quoted in Farwell, The Great Boer War, p 244.

38. Humphreys, "Black and White Budget", 15 September 1900, quoted in Farwell, The Great Boer War, p 245.

39. Farwell, The Great Boer War, pp 243-246.

40. Burdett-Coutts, The Sick and Wounded in South Africa, p 119.

41. Farwell, The Great Boer War, p 248.

42. E. Bradlow and A. Bradlow, "The Dilemma of Frederick Treves: A Civilian Surgeon in the Royal Army Medical Corps during the South African War of 1899-1902", RUSI Journal, 152 (June 2007), p 85.

43. See De Jong, Buitelandse Ambulances; H. Ferreira, "Die Nederlandse Ambulanskorpse in Suid-Afrika", MA dissertation, University of the Free State, Bloemfontein, 1981; J.C. 
errors and put them right, but in time the British military adopted a less conciliatory stance. For this, Ferreira contends, there was some justification because the Geneva Convention made no provision for guerrilla warfare. ${ }^{44}$ However, it should also be seen as retaliation for Boer abuses and as a demonstration of the wearing thin of mutuality in an asymmetric conflict. This was the context in which Alexander Russell, a cavalry doctor, mused:

I think it is now time to abolish the Red Cross in this war. If we don't completely respect the Red Cross of the Boers, we should claim no privilege for our own. To destroy 20 farms in one day and then expect the owners to be in a calm and Christian frame of mind and remember all the Articles of the Geneva Convention is too much. Let us fight to recover our wounded and the RAMC will go wherever the troops will. 45

\section{Civilian doctors}

The army was increasingly dependent on civilian doctors and by the end of the war the bulk of the medical personnel were not RAMC trained. However, like the RAMC, the civilian doctors were under military orders and subject to the heavy demands of military bureaucracy. ${ }^{46}$ When the British-born civilian doctor Henry Taylor was put in charge of a Colonial army hospital in Ficksburg, he found that he was not able to visit his patients after dark because as a civilian he had to obey curfew regulations. The only resolution that could be offered to this enigma was that the hospital be taken over by the imperial army and Taylor relieved of his duties. ${ }^{47}$

\section{The concentration camps}

In the concentration camps the civilian doctors in army employ proved inadequate in a situation of heightened patient vulnerability in a cross cultural environment and across power differentials. ${ }^{48}$ Many of the doctors employed in the camps were simply unsuitable, "the military having drained South Africa of those who were suitable. ${ }^{49}$ Doctors were in short supply and the appointment of medical staff was resisted on the grounds of economy. At a time when the Bloemfontein camp had only one doctor

de Villiers, "The Medical Aspect of the Anglo-Boer War, 1899-1902, Part 1", Military History Journal, 6, 2 (1983).

44. Ferreira, "Die Nederlandse Ambulanskorpse", p 101.

45. Robertson (ed.), Cavalry Doctor, 15 November 1901, p 311.

46. Spiers, The Late Victorian Army, p 324; Bradlow and Bradlow, "The Dilemma of Frederick Treves", p 85.

47. P. Hadley (ed.), Doctor to Basuto, Boer and Briton 1877-1906: Memoirs of Dr Henry Taylor (David Philip, Cape Town, 1972), pp 176-177.

48. J. Leaning, "Medicine and International Humanitarian Law", British Medical Journal, 319, 7207 (14 August 1999), p 394.

49. Free State Provincial Archives (hereafter FSPA), Archives of the Colonial Secretary, Orange River Colony (hereafter C0) 27.1341, Gould-Adams, Report dated 4 May 1901; R. van Reenen (ed.), Emily Hobhouse: Boer War Letters (Human \& Rousseau, Cape Town), 15 April 1901, p 104. 
for 3000 inmates, Captain Arthur Trollope, the chief superintendent of camps in the Orange River Colony (ORC), was reluctant to engage another. ${ }^{50}$ According to him, there were no civilian doctors "who are desirable characters". ${ }^{51}$ In the end, fully half of all the civilian doctors appointed were discharged or resigned. ${ }^{52}$

When the inevitable disaster struck, doctors like Sir Kendal Franks, seconded from the army to report on the camps, allowed political loyalty to override humanitarian concern by scapegoating the victims of the disaster. ${ }^{53}$ As agents of the British imperial mission, camp doctors were often blind to the reality that their Victorian preconceptions and practices constituted an attack on the Boer way of life, and they were therefore incapable of bridging the gap in medical cultures. ${ }^{54}$ Emily Hobhouse believed that the attitude of medical staff had a great deal to do with the aversion of Boer women to the medicine practised in the camps. ${ }^{55}$ In this regard, some camps were less fortunate than others. Trollope described John Graham of the Vredefort Road camp as "rather a bad lot"; William Beor neglected his duties in the Harrismith camp; and the Ladies' Commission urged the dismissal of John Polson of Heilbron. ${ }^{56}$ In the Bethulie camp, Fredrick Madden was regarded as incompetent, Augustus Dickenson and John Barrett were dismissed for drunkenness and Percy Carte was recommended for transfer. ${ }^{57}$

On the other hand, Arthur Webb, seconded from the RAMC, to the Springfontein camp was energetic and painstaking and put excellent sanitary conditions in place. ${ }^{58}$ The chief superintendent exerted himself to retain Norman Pern's services in the Bloemfontein camp, because "he takes a great interest in his work and now thoroughly knows all the people".59 Winburg camp had the services of Dr Theodore Molesworth. Although Molesworth came out from England to work in the camp, he was very sensitive to the cultural aspect of medical practice, believing that someone who could speak the language and take a personal interest in the inmates was best suited to working in the camp. He had the highest regard for Maria

50. E. van Heyningen, Concentration Camps of the Anglo-Boer War: A Social History (Jacana, Johannesburg, 2013), p 88.

51. Quoted in Van Heyningen, Concentration Camps, p 226.

52. That is, 47 out of 94. Spies, Methods of Barbarism? p 200.

53. Van Heyningen, Concentration Camps, p 188.

54. See also E. van Heyningen, "A Clash of Cultures: British Doctors versus Boer Women", in B. Nasson and A.M. Grundlingh (eds), The War at Home: Women and Families in the Anglo-Boer War (Tafelberg, Cape Town, 2013), p 130.

54. S.V. Kessler, "Medical Services in Black Concentration Camps January-August 1901", Paper presented at "The Anglo-Boer War: A Reappraisal" Conference, University of the Free State, Bloemfontein, 12 to 15 October 1999), p 7.

56. FSPA, Archives of the Chief Superintendent of Refugee Camps (hereafter SRC) 8.7007.

57. See E. van Heyningen, "British Concentration Camps of the South African War", http://www2.lib.uct.ac.za/mss/bccd/Histories/Bethulie/, accessed 1 June 2017.

58. Van Heyningen, "British Concentration Camps", http://www2.lib.uct.ac.za/mss/bccd/ Person/1992/Arthur Lisle Ambrose Webb/ accessed 31 August 2017.

59. Van Heyningen, "British Concentration Camps", http://www2.lib.uct.ac.za/mss/ bccd/Person/1992/Person/420/Norman Pern, accessed 31 August 2017. 
Bakkes, a dedicated Dutch nurse who worked unstintingly in the camp and was loved by the inmates. When a second Dutch nurse Sister Alma became available he pleaded that she be employed too, urging that it would contribute greatly "to reconciling the people and reconciling them to our Government".60 However, Sister Alma's appointment was blocked by the military authorities on account of her pro-Boer sympathies. ${ }^{61}$ Thus a doctor's legitimate concern was overridden by an army order. Nor is this the only instance of military interference in the running of a camp. The local military commandant repeatedly countermanded the decisions of the superintendent of the Heilbron camp. The commandant at Vredefort Road was a constant source of conflict in the camp; and Smith, the superintendent of the Brandfort camp complained of the military authorities obstructing his work. ${ }^{62}$

In the black concentration camps, the inmates were even more vulnerable than their white counterparts. They had to construct their own huts; they were obliged to cultivate crops for themselves and for the army and were provided with only the most basic implements; their sanitary arrangements were more primitive; and medical care was virtually non-existent. ${ }^{63}$ According to the official returns, 14154 people died in these camps, but the records are defective and the death toll may have as high as 25000 - some 80 per cent of them children. ${ }^{64}$ More horrifying than the bare statistics is Kessler's cogent argument and his conclusion that most of the deaths from measles and typhoid and other water-borne diseases in both the black and white camps could have been avoided. ${ }^{65}$ But it was standard British colonial medical policy, he contends, "to only provide medical care for indigenous people when failure to do so would induce epidemic diseases and thereby pose a threat to the health of the military and white population or disrupt the labour supply". 66

If this judgement is excessively harsh, it is in striking contrast to the seemingly cavalier attitude of British officialdom. In August 1901 when the annual mortality rate in the black camps in the Orange River Colony rose to a staggering 170 per thousand

60. FSPA, SRC 13.4797.

61. FSPA, SRC 12.4901.

62. Van Heyningen, "British Concentration Camps", http://www2. lib.uct.ac.za/ mss/bccd/Histories/Bethulie/;...Heilbron/;/Vredefort Road/; and/Brandfort/, accessed 31 August 2017.

63. Van Heyningen, Concentration Camps, p 154; B.E. Mongalo and K. du Pisani, "Victims of a White Man's War: Blacks in Concentration Camps during the South African War (1899-1902)", Historia, 44, 1(1999), pp 160-161; T. Matsetela, "The Life Story of Nkgomo Mma Pooe: Aspects of Sharecropping and Proleterianization in the Northern Orange Free State", in S. Marks and R. Rathbone (eds), Industrialization and Social Change in South Africa: African Class Formation, Culture and Consciousness 1870-1930 (Longman, Harlow, 1982), p 220; Van Heyningen, Concentration Camps, pp 156, 172.

64. S. Kessler, "The Black Concentration Camps of the South African War 1899-1902", PhD thesis, University of Cape Town, 2003, p 376.

65. Kessler, "The Black Concentration Camps", p 294.

66. Kessler, "The Black Concentration Camps", p iii. 
per annum 67 (compared to 28 per thousand in the white camps), Dr George Pratt Yule, the medical officer of health in the ORC, was able to indulge the British obsession with the beneficial effects of ventilation, a source of much contention in the white camps, ${ }^{68}$ in his jaunty appraisal:

The health of the camps is exceedingly good ... better in fact than the white camps. This is probably due to the imperfect nature of the shelters erected by the natives which allow of a perfect ventilation by numerous crevices and holes in the walls. ${ }^{69}$

In November, when the death rate had risen to 355 per thousand, Captain C. Wilson Fox, head of the Native Refugee Department in the ORC, opined that the death rate "appears high, but, under the circumstances, not excessive". ${ }^{70}$

\section{Boer doctors}

The vicissitudes of Boer doctors during the war reflect the way in which non-medical constraints could impede their ability to carry out their professional responsibilities. The underutilised archival records of the Central Judicial Commission (CJC), ${ }^{71}$ held in the National Archives in Pretoria, are an indispensable resource in determining how Boer doctors were affected by the ambiguities inherent in medical practice in an occupied country. They are of a very varied nature and although they need to be interrogated and interpreted in terms of provenance, bias, internal inconsistencies and misrepresentations, they are intensely personal, providing a compelling picture people's actions in the anguished context of trying to get on with their ordinary lives in the face of extraordinary circumstances. The records of the Senior Superintendent of Refugee Camps (SRC) in the Free State Provincial Archives, Bloemfontein, bear eloquent testimony to the crippling frustrations endured by doctors who served in the concentration camps. These records have been comprehensively researched by Elizabeth van Heyningen, to whose writings frequent reference is made.

\section{Boer patriotism}

Ardent pro-Boer feeling could also lead to medical personnel avoiding treatment of British sick and wounded or even abusing Red Cross immunity. Here one must include foreign doctors because many Dutch people who came to South Africa at the turn of the century were imbued with a fervent cultural nationalism which embraced

67. J.S. Mohlamme, "African Refugee Camps", in F. Pretorius, (ed.), Scorched Earth (Human \& Rousseau, Cape Town, 2001), p 120; Warwick, Black People and the South African War, p 151.

68. See also E. van Heyningen, "British Doctors versus Boer Women", in Pretorius (ed.), Scorched Earth, p 188.

69. FSPA, CO 50.2976/01, Report of MOH, G. Pratt Yule, 17 August 1901.

70. FSPA, CO 50/29, Native Refugee Camp Returns for November.

71. NASA, Archives of the Central Judicial Commission (hereafter CJC). 
the Boers as their kinsmen. ${ }^{72}$ This may well have been the case with Dr Franz Piper. His late arrival in Winburg, where he was admitted to practise in August 1899,73 only months before the outbreak of the war, suggests that he may have come to the Free State specifically to aid the Boer cause. He served in the Johannesburg Red Cross hospital based in Colesberg, but the advance of General Clements's troops obliged him to return to the Free State. ${ }^{74}$ Obscurity surrounds his further actions, although the Boer nurse, Betty Wessels, mentions having seen him in Pretoria on 31 May 1900 and in Nelspruit on 29 August and 11 September. ${ }^{75}$ This suggests that he accompanied the Boer retreat and possibly left the country on one of two Dutch ambulance trains headed for Lourenço Marques. In November 1902, "the widow Piper" was granted permission to occupy a small portion of the farm Uitroep in the Bethlehem district until June 1903, "by which time she should be able to make future arrangements for herself and family",76 but there is no indication here or elsewhere as to who her husband was.

A local doctor who was equally determined to escape any taint of collaboration with the British authorities was Alfred Ramsbottom of Bloemfontein. This Irishtrained doctor was in charge of the Free State ambulance service. When positional warfare ceased to be the norm, the use of ambulances was discontinued and Ramsbottom accompanied the Free State government in the field until June 1900, when he joined Hertzog's commando, in which he served to the bitter end. ${ }^{77}$

\section{Abuse of immunity}

The most blatant abuse of immunity perpetrated on the Boer side occurred when 46 members of the Chicago Irish-American ambulance (but excluding the doctors) and some personnel of the Belgian ambulance who had entered the country under Red Cross aegis became Boer combatants. ${ }^{78}$

There were also reports of Boer doctors abusing the immunity of foreign ambulances; ${ }^{79}$ most strikingly, Dr Esaias Snyman of Ventersburg was accused of transporting ammunition in ambulance wagons. The resident magistrate of Winburg, St John Cole-Bowen, describes Snyman as "a really sound man, well spoken of by

72. See P. de Klerk, "Nederlandse Nasionalisme en Afrikanernasionalisme - 'n Vergelyking", Koers, 61, 3 (1996), pp 323-344.

73. FSPA, Archives of the Government Secretary (hereafter GS), 2090 R5329/99.

74. De Villiers, Healers, Helpers and Hospitals, volume I, p 586, and volume II, p 15.

75. Wessels, "Diary of Betty Wessels", pp 15, 55 and 62.

76. FSPA, Archives of the Director of Land Settlement (hereafter DLS), 13.A1290, Major A.P. Apthorp, Secretary, Land Settlement, to the Resident Magistrate, Bethlehem, 4 November 1902.

77. A.P.J. van Rensburg, "Ramsbottom, Alfred Ernest William", in C.J. Beyers (ed.), Dictionary of South African Biography III (HSRC, Pretoria, 1977), p 700.

78. De Villiers, Healers, Helpers and Hospitals volume I, pp 348, 396, 402, 552.

79. De Jong, Buitelandse Ambulances, pp 19-20, 35; Robertson (ed.) Cavalry Doctor, 3 June 1900, p 45, and 8 May 1901, p 240. 
everyone, British and Boer alike", 80 and ascribes the charge against him, which led to his deportation to India, to the malice of "an informant (now deceased) who was activated by private spite owing to a quarrel between him and Claimant before the war". 81 This informant was a Free State burgher called Thomas Harvey. When the war broke out, Harvey left Ventersburg to join Rimington's Horse somewhere near Noupoort. ${ }^{82}$ On 8 May 1900, the 2nd Netherlands Ambulance, which was heading for Kroonstad, was apprehended by a British patrol. Among them, Betty Wessels noted, was "an Afrikander named Harvey". He accused the Boers of conveying ammunition. Later that evening, some fifty shots were fired at the ambulance, presumably by Harvey's patrol.83 Somewhere near Kimberley, Harvey came across Snyman's ambulance men and told them that he would do Snyman all the harm he could. As a result of his machinations, Snyman was not only deported but, contrary to the orders of Bruce Hamilton and three days after the destruction of the rest of Ventersburg, his house was wantonly destroyed. ${ }^{84}$

The ambiguities of Snyman's situation were mirrored in his family. He was one of five sons of Johannes Snyman of Ventersburg, who "did not at all fall in with the conduct of his son [and] who treated all alike with courtesy and consideration". 85 One of his brothers was the clergyman, Christoffel Snyman, who was deported because as a Dutch Reformed minister he had a great deal of power but was "not using it sufficiently in the interests of the British". ${ }^{86}$ Of the other three brothers, one never went on commando, another served with the British and the third was a bittereinder.

Again an excess of pro-Boer sentiment might lead to a Boer doctor abusing his immunity in order to spy on the British. This charge was brought against Fritz Reich, a German-born doctor who practised in Senekal. After surrendering in May 1900, Reich was put in charge of the British hospital in that town. ${ }^{87}$ According to Reich, Sir Lesley Rundle asked him to attend to the Boer general A.I. de Villiers, who was mortally wounded at the battle of Biddulphsberg and for whose care Rundle had accepted responsibility. Reich treated De Villiers for two and a half months before sending him to the hospital in Bloemfontein. After the war, Reich wrote to Rundle asking him to certify that this was indeed the case. Rundle passed the request on to Colonel May, his principal medical officer, who replied that De Villiers could have

80. Resident magistrate's note in NASA, CJC 692.151.

81. NASA, CJC 692.151.

82. NASA, CJC 699.309: T. Harvey.

83. Wessels, "Diary of Betty Wessels", 8 May 1900, p 1.

84. NASA, CJC 692.151. Captain Thomas Harvey died in British service at Strydenburg on 1 March 1901 of wounds received. See S. Watt, In Memoriam: Roll of Honour Imperial Forces Anglo-Boer War 1899-1902 (University of Natal Press, Pietermaritzburg, 2000), p 183.

85. NASA, CJC 691.150: J.J. Snyman; Resident magistrate's report.

86. NASA, CJC 691.131: C.J. Snyman.

87. NASA, CJC 702.365: F. Reich. 
been treated by a British army doctor but had asked that Reich treat him ${ }^{88}$ and that "the transaction was therefore purely a private one, with which the British Government has nothing to do". ${ }^{89}$ As Reich pointed out, this version of events was ruled out on two counts: General de Villiers was unacquainted with him and, as a result of brain damage, was unconscious throughout.

May's response was indicative of deep hostility towards Reich, which came about in this way. While serving at the hospital, Reich had obtained a pass from Colonel T.D. Pilcher to buy provisions in Winburg and allegedly made use of the opportunity to engage in some espionage. As a result, the post of the Winburg cattle guard under Sergeant R. Allen was surprised on 28 June 1901 and Allen and ten privates were obliged to surrender. The British authorities discovered the alleged source of the Boer intelligence from a captured artilleryman, Corporal Zacharias Hayward. Reich was arrested at the end of August 1901, imprisoned in Winburg and, three weeks later, obliged to accept voluntary repatriation to Germany. ${ }^{90}$

On the face of it, Reich betrayed the British and deserved to have his subsequent compensation claim for damage suffered during the war, amounting to close on $£ 2100$, disallowed. However, there are a number of circumstances that suggest that here, as in so many other cases, military justice may equate with injustice. Firstly, the evidence against Reich was obtained from an unheroic and perhaps unreliable source. Hayward had been found hiding unarmed in a cave at Tafelberg near Senekal. ${ }^{91} \mathrm{He}$ was deported to India but offered to provide information in exchange for the chance of returning to South Africa. The first intelligence with which he whetted the military's appetite was that Hendrina Joubert, widow of the commandant-general, was a conduit not only for intelligence but also for arms and ammunition..$^{92}$ Secondly, Reich was not put on trial but imprisoned for three weeks and then offered the alternative of voluntary repatriation. Thirdly, on arrival in Germany he immediately approached the British War Office with the urgent request that he should be afforded the opportunity of exonerating himself from "the absolutely untrue and monstrous accusation, that I was proved to be a spy". The response to this was that Earl Roberts had made no accusation against Reich of being a spy and was "unable to cause any investigation to be instituted as to any remarks"93 anyone else may have made. Reich was so agitated about the dishonour he had to endure that he next asked the German army, in whose employ he now was, to investigate the allegation. In a memorandum from the British government the whole

88. NASA, Archives of the Private Secretary of the Governor (hereafter GOV) 846, PS18/243/05, Letter from Reich to the High Commissioner, Earl Selborne, dated 14 November 1905.

89. Letter from Col. May, dated 17 May 1903, quoted by Reich in his letter to the High Commissioner.

90. FSPA, CO 92.3318.

91. NASA, Archives of the Provost Marshal's Office (hereafter PMO) 54.3760.

92. NASA, PMO 35.2371, a claim not devoid of truth.

93. NASA, GOV 846 PS18/243/05, Reply from War Office, received in January 1904 and quoted by Reich in his letter to Earl Selborne, dated 14 November 1904. 
issue of guilt was neatly side-stepped by the disingenuous argument that as Reich was a citizen of the (non-existent) Orange Free State at the time of the alleged incident, "in the opinion of the British Government therefore the service which the abovenamed rendered to his countrymen of that time could not do any harm to his honour". ${ }^{94}$ In trying to vindicate himself, Reich wrote numerous letters urging that his claim for compensation should be paid. On 14 November 1904 he petitioned the high commissioner, the Earl of Selborne, that as he "never did any dishonourable work", he was entitled to payment, to which Selborne replied that no good purpose would be served by re-opening the matter and that, in any case, all the available funds had been disbursed. 95

Equally hurtful and probably equally spurious was the accusation of communicating with the enemy levelled against another Boer doctor, Reinhard Reinecke. He was a British subject practising in Ceres in the Cape Colony, but a Boer sympathiser who had practised in Senekal before the war. He sought to balance the equation by strict adherence to a professional code of conduct. "I never hid my feelings of sympathy with the people amongst whom I lived and made my fortune", 96 Reinecke wrote, but to some minds his status as a member of the Red Cross Society of Geneva was irrelevant and he was quite simply "a British subject and a rebel". ${ }^{97}$

On the outbreak of war, with the knowledge and assistance of Lord Milner, Reinecke had returned to the Free State, accompanied by Dr Anthonie Gijsbert Viljoen of Caledon and Dr Pieter Gideon Cilliers of Worcester, as head of the volunteer ambulance organised by friends of the Boer cause in the Cape Colony. ${ }^{98}$ At Albertina station in Van Reenen's Pass he and Cilliers ran a field hospital which enjoyed an excellent reputation. ${ }^{99}$ At the end of January 1900, Reinecke moved his ambulance closer to the commandos around Ladysmith and, in the course of the next two months, treated 234 in-patients, as well as many out-patients. ${ }^{100}$ According to his own account, Reinecke also treated British wounded at Spioenkop, but, he adds scrupulously, this was only because he was asked to volunteer his assistance. ${ }^{101}$ In May 1900 he joined in the general Boer retreat and returned to his practice in Ceres with the consent of the British authorities. ${ }^{102}$

When the Cape Colony was invaded by Boer forces and Ceres was threatened, Reinecke offered his services to the resident magistrate and the principal medical officer, but they were declined. In Ceres he treated British soldiers but this was for

94. Memorandum dated 5 March 1904, quoted by Reich in his letter to Earl Selborne.

95. NASA, GOV 846 PS 18/243/05.

96. TAB, CJC 215.1610: R.J. Reinecke, Statement dated 1 September 1904.

97. Anonymous annotation in the same file.

98. Obituary, Dr R.J. Reinecke, South African Medical Journal, 22 August 1936, p 590.

99. Zuster Hellemans, Met het Roode Kruis mee in den Boeren-Vrijheidsoorlog (Gebroeders Koster, Amsterdam, 1901) p 37.

100. De Villiers, Healers, Helpers and Hospitals, volume I, p 391.

101. TAB, CJC 215.1610.

102. De Villiers, Healers, Helpers and Hospitals, volume I, p 391. 
payment and by virtue of his profession. In August 1901, Reinecke was suspected of communicating with the enemy. Brigadier-General H.H. Settle described him as "a well known disloyal British subject",103 and on 18 September he was charged with actions prejudicial to public safety and deported to Malmesbury as an "undesirable". During the seven months he spent in Malmesbury, nothing was proved against him and no inquiry was held. Tired of clicking his heals, Reinecke offered to serve at any hospital at the military base. In May 1902 he appealed to Kitchener for an investigation but this was refused. ${ }^{104}$ According to Reinecke's anonymous obituarist, his wartime experiences:

... saddened and embittered him, for his difficulties were caused not by any disloyal act on his part, but by sheer spitefulness on the part of those who saw in every manifestation of sympathy with the Boer Republicans an indication of high treason. ${ }^{105}$

\section{Dual nationality}

Some Free State doctors - for example John Leach, Francis Wilson and Paul Gillespie were both British subjects and naturalised burghers. This could have been a source of conflict, but it is striking how easily some English-speaking burghers who had been in the country for many years stepped back into their Englishness the moment the British troops appeared on the scene. ${ }^{106}$ Leach exemplified this trend.

Commandeered by the Boers for medical duty, Leach did not respond. Instead he greeted the approach of the British by sending a wagon-load of potatoes to the farm Roodekraal for Macdonald's column and, on the occupation of Ventersburg, signed the oath of neutrality. In doing so, he could not foresee the changing fortunes of war. When the garrison was withdrawn, the list of 50 to 60 men who had signed the oath was left behind for the returning Boers to find. The signatories were arrested but later released. Ventersburg again came under British control, so the Boers who had instigated their arrest were themselves arrested. ${ }^{107}$ Under pressure from the Boers, Leach relocated to the Cape Colony, leaving his farm to the tender mercies of the British army. When a column under Colonel E.C. Williams and Major Edward PineCoffin visited Leach's farm on 6 March 1901, the troops removed the furniture from his house, including a truckload of imported furniture, still in fifteen original packing cases, to use as firewood. William Thomson, who was acting as a guide to the column, pointed out to Pine-Coffin that Leach was a loyal British subject, but these objections were brushed aside, saying that it was "absolutely necessary" to have some means of

103. NASA, PMO 46.3143: Brigadier-General H.H. Settle, Cape Town, to Secretary of State for War.

104. TAB, PMO 46.3143: General Settle to Secretary of State for War; TAB CJC 215.1610. See also J.A.C. Reinecke, 'The Reinecke Family in South Africa', Familia, 23, 2 (1986), p 32 .

105. South African Medical Journal, 22 August 1936, p 590.

106. Boje, An Imperfect Occupation, p 75.

107. NASA, CJC 699.144. 
cooking the men's food.108 It would seem that Leach did not accept these depredations with equanimity, for the resident magistrate of Winburg, sums him up by saying: "Loyal to the British but talks too much".109

Francis Wilson was not only British by birth and a burgher by residence; he also had a Boer wife. In these circumstances, he defined his national sentiment in negative terms by saying that he was "not a Boer hater but not pro-Boer". ${ }^{110}$ When the Boers sought to recruit his services, he took refuge in Basutoland, leaving his family on his farm. When Boers threatened to burn his house down, he returned with a view to removing his family to safety. The Boers arrested him and paroled him to his farm, where he remained until September 1901 when he was visited by the 1st King's Dragoons on a farm-burning mission. Afterwards he went to the camp of Lord Basing, their commanding officer, on a neighbouring farm, where he saw remains of his furniture and his library of 300 books. He seems to have felt no rancour towards the British, but prided himself on serving them as a medical officer with Bethune's column and by providing them with information. ${ }^{111}$ Wilson and his family were "brought in" by Bethune's column on 12 September $1901^{112}$ and for the next month he and his son were resident in the Winburg concentration camp, ${ }^{113}$ but the camp register offers no indication on the whereabouts of his wife.

In December 1901, Wilson applied from Ficksburg for a position in any concentration camp but specified that for private reasons, he did not want a medical appointment. He clearly hoped to secure an appointment as a camp superintendent because he makes a point of saying that he had had much experience in managing large numbers of emigrants in the service of various shipping lines. He was strictly temperate, in robust good health and could speak Dutch, Sesotho, French and German. Wilson was promptly offered a position as medical officer in the Bloemfontein camp, where a doctor was sorely needed, but when he indicated that he proposed bringing his family with him, the appointment was cancelled because the commandant of Ficksburg would not allow his pro-Boer wife to remain in Ficksburg if he was not there to keep an eye on her, while the military authorities in Bloemfontein would not allow her to live there either because they had "quite enough of this sort in town already".114

In the case of Paul Gillespie there is greater complexity because he was a Canadian, and therefore a British subject, as well as a naturalised burgher of the Free State who was well integrated into the Boer community. When the war broke out, Gillespie offered his services to the British high commissioner, but Milner declined

108. Quoted in NASA, CJC 691.144: J.R. Leach.

109. NASA, CJC 691.144.

110. FSPA, SRC 35.34.

111. NASA, CJC 200.1227: F. Wilson.

112. NASA, CJC 200.1227.

113. FSPA, SRC 90: Winburg Camp Register, p 139.

114. FSPA, SRC 35.34 and 35.35. 
them on the grounds that civilian doctors would not be needed to assist the RAMC. ${ }^{115}$ Gillespie then joined the Boer ambulance attached to the Boshof commando on the western front. He subsequently served in the Free State Ambulance near the Colesberg-Philippolis road bridge, but in January 1900 the increasing number of typhoid patients in the Boshof hospital prompted his return to that town. ${ }^{116}$ In March 1900, Gillespie was taken prisoner by the Boers and put over the Cape border for distributing Roberts's proclamation offering protection to burghers who surrendered. Margaret Marquard, wife of the local Dutch Reformed minister, was deeply distressed by this development, which, from her point of view, does not appear to have been entirely unexpected. "I hope he will be true [getrou = loyal]", she had written when he left for the front; 117 now she lamented: "This of Dr G. has haunted me. Why did he meddle with these matters instead of sticking to Ambulance Work!"118 When Winburg fell, Gillespie returned to the town, took up practice under General Clements's Brigade and was later appointed district surgeon. ${ }^{119}$ In neat counterpoint to Margaret Marquard, the Intelligence Department reported that "he does not mix himself in any way with politics" and the provost marshal described him as "thoroughly loyal".120

\section{Boer doctors in the concentration camps}

Boer doctors who served as medical officers in various concentration camps demonstrate the ambiguities inherent in medical practice in a country at war. Their situation is encapsulated in the provost marshal's comment on Caleb Schnehage: "Pro-Boer in sentiment, he has worked for a long time as a doctor in the Refugee Camp and done his work very loyally to British interests."121 This patriotic motive is also evident in the case of Alfred Baumann, who apparently was asked by President Steyn himself to abandon his studies in ophthalmology in Europe in order to serve his people in the Bloemfontein camp. ${ }^{122}$ Van de Wall in the Kroonstad camp was described as "rabidly anti-British"123 and of Henry Becker in the Bloemfontein camp it

115. NASA, CJC 161.395: P. Gillespie.

116. De Villiers, Healers, Helpers and Hospitals, volume I, p 585.

117. L. Marquard (ed.), Letters from a Boer Parsonage: Letters of Margaret Marquard during the Boer War (Purnell, Cape Town, 1967), 26 October 1899, p 40.

118. Marquard, Letters, 23 March 1900, p 65.

119. NASA, CJC 161.395 and 1696.1017: P.J. Botha.

120. NASA, CJC 161.395, Confidential reports. After the war, Gillespie continued to practise in Winburg. In 1914 he served with the South African forces in South West Africa, attaining the rank of major. In 1916 he contracted bubonic plague and, not wishing to infect anybody, isolated himself in a room of his Winburg home, where he died. See Marquard, Letters, p 40n. In the course of his life, Gillespie sought to meet the complex network of obligations imposed on him by his allegiance to Canada, Great Britain, the Orange Free State, the Union of South Africa and the Empire. In the circumstances of his death he demonstrated the simple integrity that guided his decision making.

121. NASA, CJC 693.196.

122. G. Saron and L. Hotz, The Jews in South Africa: A History, (Oford University Press, Cape Town, 1955), p 329.

123. Van Heyningen, "British Concentration Camps", http://www2.lib.uct.ac.za/mss/ bccd/Person/113/Giles van der Wall (sic), accessed 31 August 2017. 
was said that "he interested himself in politics considerably and is anti-British in the extreme". ${ }^{124}$ Yet these doctors did exemplary work and their services could not be dispensed with. By taking up appointment under the British authorities in the camps, where they endured endless frustrations, they could best serve their own people.

Stowell Kessler points out that the British army medical service had the knowledge, equipment and technology to reduce the death rate in the camps and, as these camps were situated along the railway, they could have met the needs of the camps more adequately. ${ }^{125}$ However, the army and the railways administration had other priorities. Kitchener's systematic application of the scorched earth policy involved the removal of thousands of civilians from their homes to the camps, and the primary function of the railways, now called the Imperial Military Railways, was to keep his army supplied, leaving the camps with acute shortages. ${ }^{126}$

Orderly administration of the camps was rendered impossible by the vast number of people brought in. Camp doctors warned of the consequences of "the indiscriminate massing together of people of all sorts from different parts of the Colony in a large camp, whereby no doubt contagion is bound to assert itself",127 but the troops kept bringing people to already overcrowded camps and moving them around without any prior notification. On 9 August 1901, 3000 arrived at the Brandfort camp with only 25 tents available to accommodate them. ${ }^{128}$ In the Winburg camp, the problem of overcrowding became a serious one as early as April 1901 when 250 people were brought in who had to be accommodated in the church. ${ }^{129}$ Between June and October, the camp doubled in size - from 1506 to 3 178. In August, the medical officers had warned that the camp was beginning to be overcrowded.130 At the end of that month, 720 people were transferred from Bloemfontein, when Winburg could only accommodate 250 and they brought measles and whooping cough with them. ${ }^{131}$ In January 1902 the military authorities deposited no fewer than a hundred unfortunate people at the Winburg camp without any prior notification. ${ }^{132}$ In February 1902, with people still being brought in by the troops ${ }^{133}$ - despite Kitchener's order to the contrary - the possibility of demolishing an adjacent rifle

124. FSPA, Archives of the Military Governor, Bloemfontein (hereafter MGB) 3-4, 18 August 1900, quoted in Van Heyningen, Concentration Camps, p 89.

125. Kessler, "The Black Concentration Camps", p 247.

126. Van Reenen (ed.), Emily Hobhouse: Boer War Letters, p 79.

127. Cd 819, p 94, Report of Dr Henry Becker, quoted in A.W.G. Raath and R.M. Louw, Die Konsentrasiekamp te Bloemfontein gedurende die Anglo-Boereoorlog 1899-1902 (War Museum of the Boer Republics, Bloemfontein, 1993), p 143.

128. Cd 819, p 292.

129. FSPA, SRC 6.RC1796: Monthly Report, Winburg Refugee Camp.

130. FSPA, SRC 12.4454: Medical report, pp. 3-4.

131. FSPA, SRC 13.5042; FSPA, CO 417.350, Report on Burgher Camp at Winburg, p 8.

132. Report of the Chief Superintendent of Refugee Camps in the Orange River Colony for the Month ending 31 January 1902, p 11.

133. About 100 men women and children in January 1902. On this see also FSPA, SRC 19.7444: Letter from Gould-Adams to Lord Kitchener. 
range in order to allow for expansion westwards was raised, but the commandant, Colonel Crosbie, was adamant that it was impossible to relinquish it. ${ }^{134}$

As principal medical officer in the Kroonstad concentration camp, Gilles van de Wall constantly drew the authorities' attention to problems such as overcrowding. ${ }^{135}$ To reduce the numbers in his camp, 700 people, including ten families suffering from measles, were moved from Kroonstad to Heilbron, despite instructions from A.G. Trollope, chief superintendent of the ORC camps, that all such movements were to cease until the epidemic had abated. Van de Wall was blamed, but the transfer took place on military instructions in the face of his objections. ${ }^{136}$ Although the medical crisis in the camps enhanced the status of doctors in relation to the camp superintendents, ${ }^{137}$ their wishes counted for little with the military authorities.

Overcrowding in the camps was exacerbated by malnutrition. In August 1901 a case of scurvy was reported in Winburg camp. As no fresh vegetables were issued in the camp, the doctors asked for a supply of lime juice to avoid an epidemic of this disease, ${ }^{138}$ but by the end of September it had still not been received. ${ }^{139}$ The meat supplied to all the camps was notoriously objectionable, "often inedible, lacking in fat, sometimes diseased, occasionally bad". ${ }^{140}$ On more than one occasion, John Graham at Vredefort Road, rejected consignments of meat, using such descriptions as "absolutely rotten". 141

When the doctors in the Kroonstad camp, Edmond Symonds and Van de Wall, expressed concern about the food provided for sick children in the Kroonstad camp, the chief superintendent refused to modify their diet on the grounds of economy. ${ }^{142}$ Thomas Last of Brandfort indented for bedding for inmates who were sleeping on the ground, but met with the same response. ${ }^{143}$ When the Winburg superintendent applied for articles of clothing in March 1901, he was urged to "pay more careful attention to economy",144 and Trollope urged "strict economy" in the issuing of

134. FSPA, SRC 19.7442.

135. Van Heyningen, "British Concentration Camps, http://www2.lib.uct.ac.za/mss/ bccd/Histories/Kroonstad/, accessed 31 August 2017.

136. A.C. Martin, The Concentration Camps 1900-1902: Facts, Figures and Fables (Timmins, Cape Town, [1957]), p 48, with reference to Cd 819, p 293.

137. E. van Heyningen, "Women and Gender in the South African War", in N. Gasa (ed.), Women in South African History: Basus'iimbokodo Bawel'imilambo (HSRC, Pretoria, 2007), p 99.

138. FSPA, SRC 12. 4454, 4538.

139. FSPA, SRC 13.5042.

140. Van Heyningen, "Women and Gender", p 95.

141. FSPA, SRC 13.5021. See also A.W.G. Raath and R.M. Louw, Die Konsentrasiekamp te Vredefortweg gedurende die Anglo-Boereoorlog 1899-1902 (War Museum of the Boer Republics, Bloemfontein, 1992), p 87.

142. FSPA, SRC 2.1103, monthly medical report, 1 April 1901.

143. FSPA, SRC 1.126.

144. FSPA, SRC 3.666 and 533; cf. SRC 12.4516 for a similar instruction to Bethulie. 
soap. ${ }^{145}$ Bethulie was without adequate supplies for many months with "families on the verge of starvation", 146 and when the superintendent at Bloemfontein indented for urgently needed tents, he was advised that the troops also needed tents. ${ }^{147}$

Frustration with the inability of camp superintendents to address problems led to conflict between camp doctors and the superintendents. In the Harrismith camp, Dr Charles Rossiter felt he was obstructed by Superintendent Arthur Bradley. ${ }^{148}$ In the Winburg camp, Molesworth was at loggerheads with the two superintendents, Graham Clarke ${ }^{149}$ and Edward Alexander. Alexander complained of Molesworth's "constant nagging" and "deliberate petty annoyances" and said that if these continued, he would be compelled "to take steps to remove what threatens to become a pest to my existence". ${ }^{150}$ Dr Alfred Pierce-Green went so far as to claim that he outranked Superintendent Bradley, who was only nominally in charge of the camp. ${ }^{151}$

For Boer doctors, British notions of superiority lent an extra edge to disagreement. Thus Caleb Schnehage, who had been prevented from submitting a report on the poor sanitary conditions in the Showyard camp in Winburg to the Board of Health in Bloemfontein, 152 differed sharply from Dr Arthur Tonkin, the travelling medical inspector, who, on a visit to the camp in January 1902, reported: "The camp is just awful. The hospital is a disgrace. The sanitation is vile ...".153 Tonkin complained that there was no "English supervision" of the Showyard and, on the basis of his "English experience",154 wrongly diagnosed diphtheria and ordered the camp closed to all communication, all this without the courtesy of consulting Schnehage or Molesworth, the serving camp doctors. ${ }^{155}$

Schnehage understood that it was pointless for the camp doctors to vent their frustration on the superintendents. In the early stages of the Winburg camp's existence, water was in extremely short supply. One inmate, Cornelis van Schalkwyk of Groot Saxony characterised the shortage of water - about 4 litres a day per family

145. FSPA, SRC 3.533. Emily Hobhouse wrote that in the camps "soap is a luxury - water not superabundant". See Van Reenen (ed.), Emily Hobhouse: Boer War Letters, 4 March 1901, p 83.

146 Van Heyningen, "British Concentration Camps", http://www2.lib.uct.ac.za/mss/ bccd/ Histories/Bethulie/, accessed 31 August 2017.

147. FSPA, SRC 1.126; SRC 2.219.

148. FSAR, SRC 17/6922, 27/12/1901; Van Heyningen, Concentration Camps, p 227.

149. FSPA, SRC 13.4797.

150. FSPA, SRC 19.7321

151. FSPA, SRC 41.1359.

152. Letter from Mrs Roux, quoted in E. Hobhouse, The Brunt of the War and Where It Fell (Methuen, London, 1902), p 252.

153. FSPA, SRC 19. 7450.

154. FSPA, SRC 19. 7423, Dr Tonkin's Report on the Showyard.

155. FSPA, SRC 19.7444. 
- as the "greatest disaster" of the camp. ${ }^{156}$ A medical report dated 22 August 1901 described the supply as "absolutely insufficient" and called for urgent attention as the inmates of the camp were unable to wash. ${ }^{157}$ The main supply came from a "not very copious" spring in a nearby kloof. It was inadequate at the best of times, and when columns were in Winburg and watered their horses, it was almost impossible for civilians to obtain any water. The superintendent was quite powerless, as Schnehage put it, because "the military always goes first". 158

The diary of a clergyman, August Lückhoff, ${ }^{159}$ who served in the Bethulie camp, bears shocking witness to the strain a pro-Boer official felt in the face of the suffering of the inmates; for a competent doctor who identified with his patients but had to see them languish as a result of the conditions that prevailed in the camps prior to the visit of the Ladies' Commission, the strain would also have been very great. For a doctor the option of private practice was readily available. Schnehage worked in the Winburg camp but kept up his practice in the town. In July 1901 when the strain became too great, he wanted to leave the camp, but was persuaded to stay on until September the following year when the camp closed down. ${ }^{160}$ In his desperate plea for another doctor to be sent to Brandfort, Gilles van de Wall warned that without help his nervous system would not stand the strain. ${ }^{161}$ It requires little empathetic imagination to comprehend the inner conflict experienced by Boer doctors in the various camps who perceived that so many of the difficulties they experienced derived from or were exacerbated by the exigencies of British "military necessity".

\section{Conclusion}

There have been dramatic changes in warfare over the past century and international humanitarian law has had to be constantly adapted. The South African War occurred at a watershed between the nineteenth century, when the proportion of civilian to soldier deaths was 1:8, and the reverse ratio of 8:1 a century later. ${ }^{162}$ As a result of the development of armaments, the involvement of civilians in a total war inflicted by means of a scorched earth policy could metastasise to the aerial bombardment of cities with no military significance and the horrors of Hiroshima and Nagasaki. To cope with large numbers of wounded soldiers, triage is practised, now no longer on the humanitarian basis of the worst cases being dealt with first, ${ }^{163}$ but in accordance

156. Cornelis van Schalkwyk; see A. Barry, Ons Japie: Dagboek Gehou gedurende die Driejarige Oorlog (Afrikaanse Pers Beperk, Johannesburg, 1960), 21 August 1902, p 105.

157. FSPA, SRC 12.4454

158. FSPA, SRC 14.5385.

159. ADL [August Daniel Lückhoff], Woman's Endurance (SA News Co., Cape Town, 1904), facsimile reprint annotated by F. Pretorius (Protea Book House, Pretoria, 2006).

160. FSPA, SRC 9.3107 and SRC 43.1765

161. FSPA, SRC 10.3536, 20 July 1901.

162. Lee, Ethics and War, p 165.

163. F. Treves, The Tale of a Field Hospital, (Cassell, London, 1900), p xxi. 
with the patient's "salvage value", in other words how soon he can be back in the fighting line. 164

The distinction between military and civilians, already blurred in the South African War, was further compromised by the increase in insurgency in subsequent conflicts. The recognition of guerrilla warfare led on to the 1977 Protocols, in terms of which fighters against "colonial, alien and racist" regimes were accorded combatant status, ${ }^{165}$ but, as happened during the guerrilla phase of the South African War, such combatants could surreptitiously revert to being civilians.

Volunteers have disappeared from the battlefield; all medical personnel are part of the military machine, even the pacifist stretcher bearer. ${ }^{166}$ The problem of medical judgement conflicting with military necessity has been addressed by making senior medical officers part of the decision-making structures. ${ }^{167}$ The convention of immunity is, as we have seen, based on reciprocity. In an asymmetrical conflict, the stronger party may abandon the convention, as happened in 2002 when the Israeli army entered Palestinian towns and attacked ambulances and hospitals. ${ }^{168}$ Furthermore, in a situation where the distinction between doctors and soldiers is blurred, medical personnel are called upon to use their expertise for military purposes, whether the force feeding of IRA prisoners by Britain in 1981,169 participation in the "enhanced interrogation" of prisoners in Guantanamo Bay, Iraq and Afghanistan, ${ }^{170}$ or the military use of scientific knowledge. The World Medical Association has declared these practices unethical, ${ }^{171}$ but the stock defence is that the disputed action was taken as a member of the military, not as a doctor. 172 Furthermore, the primacy of the doctor's humanitarian concern is subverted by using medical personnel in the sporadic "Medical Civic Action Programs" implemented in Vietnam, Cambodia, Thailand, Iraq and Afghanistan for the avowedly political purpose of "winning hearts and minds". ${ }^{173}$

The dilemmas that confronted doctors during the South African War arose as a result of the conflict between medical and military concerns. Between then and now

164. Gross, "Bioethics and Armed Conflict", p 24.

165. Gross, "Bioethics and Armed Conflict", p 24.

166. M. Gross, "From Medical Neutrality to Medical Immunity", Virtual Mentor, 9, 10 (2007), p 719.

167. Benton, "British Surgery in the South African War", p 282.

168. Gross, "Bioethics and Armed Conflict", p 28; Gross, "From Medical Neutrality to Medical Immunity", p 720.

169. Gross, "Military Medical Ethics in War and Peace", in G. Lucas (ed.), Routledge Handbook of Military Ethics (Routledge, Abingdon, 2015), p 255.

170. Rochon, "Dilemmas in Military Medical Ethics", p 10.

171. Gross, "Military Medical Ethics", p 252.

172. F. Rosner, "Ethical Dilemmas for Physicians in Time of War", The Israel Medical Association Journal: IMAJ, 12, 3 (March 2010), p 134; M.G. Bloche and J. Marks, "When Doctors Go to War", New England Journal of Medicine, 352, 1 (2005), pp 3-4.

173. Gross, "Military Medical Ethics", p 256. 
these conflicts have been resolved by means of the increasing militarisation of medicine, so that in present-day conflicts it is "military necessity" that prevails.

\section{REFERENCES}

Barry, A., Ons Japie: Dagboek Gehou gedurende die Driejarige Oorlog (Afrikaanse Pers Beperk, Johannesburg, 1960).

Benton, E., "British Surgery in the South African War: The Work of Major Frederick Porter", Medical History, 21, 3 (1977), pp 275-290.

Bloche, M.G. and Marks, J.H., "When Doctors Go to War", The New England Journal of Medicine, 352, 1 (2005), pp 3-6.

Boje, J., An Imperfect Occupation: Enduring the South African War (University of Illinois Press, Urbana, 2015).

Bradlow, E. and Bradlow, A., "The Dilemma of Frederick Treves: A Civilian Surgeon in the Royal Army Medical Corps during the South African War of 1899-1902", RUSI Journal, 152, 3 (June 2007), pp 82-87. doi: 10.1080/03071840701472349

Bruderlein, C. and Leaning, J., "New Challenges for Humanitarian Protection", British Medical Journal, 319, 4207 (14 August 1999), pp 430-435.

Burdett-Coutts, W., The Sick and Wounded in South Africa: What I Saw and Said of Them and of the Army Medical System (Cassell, London, 1900).

Carver, M., The National Army Museum Book of the Boer War (Sidgwick \& Jackson, London, 1999).

De Jong, C., Buitelandse Ambulances in de Tweede Anglo-Boerenoorlog (C. de Jong, Amsterdam, 1999).

De Klerk, P., "Nederlandse Nasionalisme en Afrikanernasionalisme - 'n Vergelyking," Koers, 61, 3 (1996), pp 323-344.

De Villiers, C.J., "The Geneva Convention, National Red Cross Societies and the AngloBoer War", in A Century is a Short Time: New Perspectives on the Anglo-Boer War (Nexus Editorial Collective, Pretoria, 2005), pp 334-347.

De Villiers, C.J., Healers, Helpers and Hospitals, 2 volumes (Protea, Pretoria, 2008).

De Villiers, J.C., "The Medical Aspect of the Anglo-Boer War, 1899-1902," Part 1, Military History Journal, 6, 2 (1983).

Dyzenhaus, D., "The Puzzle of Martial Law", University of Toronto Law Journal, 59, 1 (2009), pp 1-64.

Farwell, B., The Great Boer War (Penguin Books, London, 1976).

Ferreira, H., "Die Nederlandse Ambulanskorpse in Suid-Afrika" (MA dissertation, University of the Free State, Bloemfontein, 1981).

Fuller, J.F.C., The Last of the Gentlemen's Wars: A Subaltern's Journal of the War in South Africa 1899-1902 (Faber \& Faber, London 1937).

Gill, R., "The Origins of the British Red Cross Society and the Politics and Practices of Relief in War, 1870-1906", Asclepio, 66, 1 (2014), pp 1-13.

Gross, M., "Bioethics and Armed Conflict: Mapping the Moral Dimensions of Medicine and War", Hastings Center Report, 34, 6 (2004), pp 22-30. doi: $10.2307 / 3528174$ 
Gross, M., "From Medical Neutrality to Medical Immunity", Virtual Mentor, 9, 10 (2007), pp 718-721.

Gross, M., "Military Medical Ethics in War and Peace", in Lucas, G. (ed.), Routledge Handbook of Military Ethics (Routledge, Abingdon, 2015), pp 248-264.

Hadley, P. (ed.), Doctor to Basuto, Boer and Briton 1877-1906: Memoirs of Dr Henry Taylor (David Philip, Cape Town, 1972).

Hobhouse, E., The Brunt of the War and Where It Fell (Methuen, London, 1902).

Hurst, J.E., "John McCrae's Wars", in Busch, B.C. (ed.), Canada and the Great War: Western Front Association Papers (McGill University Press, Montreal, 2003).

Kalshoven, F. and Zegveld, L., Constraints on the Waging of War: An Introduction to International Humanitarian Law (International Committee of the Red Cross, Geneva, 2001).

Kessler, S.V., "The Black Concentration Camps of the South African War 1899-1902", PhD thesis, University of Cape Town, 2003.

Kessler, S.V., "Medical Services in Black Concentration Camps January-August 1901", Paper presented at "The Anglo-Boer War: A Reappraisal" conference, University of the Free State, 12 to 15 October 1999.

Leaning, J., "Medicine and International Humanitarian Law," British Medical Journal, 319, 7207 (14 August 1999), pp 393-394.

Lee, S., Ethics and War: An Introduction (Cambridge University Press, Cambridge, 2012).

Martin, A.C., The Concentration Camps 1900-1902: Facts, Figures and Fables (Howard Timmins, Cape Town, 1957).

Matsetela, T., "The Life Story of Nkgomo Mma Pooe: Aspects of Sharecropping and Proleterianization in the Northern Orange Free State", in Marks, S. and Rathbone, R. (eds), Industrialization and Social Change in South Africa: African Class Formation, Culture and Consciousness 1870-1930 (Longman, Harlow, 1982).

Marks, S., "British Nursing and the South African War", in Cuthbertson, G., Grundlingh, A.M. and Suttie, M-L. (eds), Writing a Wider War: Rethinking Gender, Race, and Identity in the South African War, 1899-1902 (Ohio University Press, Athens, OH, 2002).

Marquard, L. (ed.), Letters from a Boer Parsonage: Letters of Margaret Marquard during the Boer War (Purnell, Cape Town, 1967).

Mohlamme, J.S., "African Refugee Camps", in Pretorius, F. (ed.), Scorched Earth (Human \& Rousseau, Cape Town, 2001), pp 110-131.

Mongalo, B.E. and Du Pisani, K., “Victims of a White Man's War: Blacks in the Concentration Camps during the South African War (1899-1902), Historia, 44, 1 (1999), pp 148-182.

Pakenham, T., "Africans in the Boer War", Review of Warwick, P., Black People and the South African War, 1899-1902, in Journal of African History, 27, 3 (1986), pp 573-575.

Raath, A.W.G. and Louw, R.M., Die Konsentrasiekamp te Bloemfontein gedurende die Anglo-Boereoorlog 1899-1902 (War Museum of the Boer Republics, Bloemfontein, 1993). 
Raath, A.W.G. and Louw, R.M., Die Konsentrasiekamp te Vredefortweg gedurende die Anglo-Boereoorlog 1899-1902 (War Museum of the Boer Republics, Bloemfontein, 1992).

Reinecke, J.A.C., "The Reinecke Family in South Africa”, Familia, 23, 2 (1986), pp. 3033.

Robertson, I. (ed.), Cavalry Doctor: Letters Written from the Field, 1900-1901 during the Anglo-Boer War by Col. A.F. Russell MB CMG (I. Robertson, Constantia, 1979).

Rochon, C., "Dilemmas in Military Medical Ethics: A Call for Conceptual Clarity", BioéthiqueOnline 4/26 (2015), http://bioethiqueonline.ca/4/26, pp 1-15, accessed 15 April 2017.

Rosner, F., "Ethical Dilemmas for Physicians in Time of War", The Israel Medical Association Journal: IMAJ, 12, 3 (March 2010), pp 133-135.

Saron, G. and Hotz, L., The Jews in South Africa: A History (Oxford University Press, Cape Town, 1955).

Schoeman, K. (ed.), Sophie Leviseur Memories (Human \& Rousseau, Cape Town, 1982). South African Medical Journal, 13 August 1921; 28 July 1934; 22 August 1936.

Spiers, E.M., The Late Victorian Army 1868-1902 (Manchester University Press, Manchester, 1992).

Spies, S.B., Methods of Barbarism? Roberts and Kitchener and Civilians in the Boer Republics, January 1900-May 1902 (Human \& Rousseau, Cape Town, 1977).

Surridge, K., "An Example to be Followed or a Warning to be Avoided? The British, Boers, and Guerrilla Warfare, 1900-1902", Small Wars and Insurgencies, 23, 4-5 (December 2012), pp 608-626. doi: 10.1080/09592318.2012.709768

Treves, F., The Tale of a Field Hospital (Cassell, London, 1900).

Van Heyningen, E., "British Concentration Camps of the South African War", http:// www2.lib.uct.ac.za/mss/bccd/

Van Heyningen, E., "British Doctors versus Boer Women", in Pretorius, F. (ed.), Scorched Earth (Human \& Rousseau, Cape Town, 2001), pp. 154-167.

Van Heyningen, E., "A Clash of Cultures: British Doctors versus Boer Women”, in Nasson, B. and Grundlingh, A.M. (eds), The War at Home: Women and Families in the Anglo-Boer War (Tafelberg, Cape Town, 2013), pp 121-141.

Van Heyningen, E., The Concentration Camps of the Anglo-Boer War: A Social History (Jacana, Johannesburg, 2013).

Van Heyningen, E., "The South African War as Humanitarian Crisis", International Review of the Red Cross, 97 (2015), pp 999-1028. doi: $10.1017 / \mathrm{S} 181638311600394$

Van Heyningen, E., "Women and Gender in the South African War", in Gasa, N. (ed.), Women in South African History: Basus'iimbokodo Bawel'imilambo (HSRC, Pretoria, 2007), pp 91-124.

Van Reenen, R. (ed.), Emily Hobhouse: Boer War Letters (Human \& Rousseau, Cape Town, 1984).

Van Rensburg, A.P.J., "Ramsbottom, Alfred Ernest William", in Beyers, C.J. (ed.), Dictionary of South African Biography, Volume III (HSRC, Pretoria, 1977), pp 699-701.

Warwick, P., Black People and the South African War, 1899-1902 (Ravan, Johannesburg, 1983). 
Watt, S., In Memoriam: Roll of Honour Imperial Forces in the Anglo-Boer War (18991902) (University of Natal Press, Pietermaritzburg, 2000).

Wessels, B., "Diary of Betty Wessels: Winburg 8th May 1900 to Lourenco Marques 19th October 1900" (Photocopy, African Stockdale Collection, University of the Free State, Bloemfontein). 